\title{
A COMPARATIVE STUDY ABOUT THE AMOUNT OF MICROPLASTIC IN POLYETHYLENE TEREPHTALATE (PET) DRINKING WATER THAT WAS EXPOSED AND NOT EXPOSED BY SUN AT ENVIRONMENTAL HEALTH LABORATORY OF POLTEKKES KEMENKES SEMARANG AT THE YEAR 2020
}

\author{
Atyaf Umi Faizah 1), Sugeng Abdullah 2), Budi Triyantoro ${ }^{3)}$, Febri Apwanti Kusumaningtyas 4) \\ Environmental Health Departement, Politeknik Kesehatan Kemenkes Semarang, \\ Jalan Raya Baturraden KM. 12 Purwokerto, Indonesia
}

\begin{abstract}
[Title: A Comparative Study About The Amount Of Microplastic In Polyethylene Terephtalate (PET) Drinking Water That Was Exposed And Not Exposed By Sun At Environmental Health Laboratory Of Poltekkes Kemenkes Semarang At The Year 2020] The majority of bottled water industry uses polyethylene terephthalate (PET) bottles as their packaging. When exposed to direct sunlight, this type of packaging is able to cause new compounds in water. Research at the State University of New York states showed that from 259 bottled water in 9 countries, 242 of them contained microplastics. The purpose of this study is to determine whether there are differences in the amount of microplastic in bottled PET containers that are exposed and not exposed to sunlight. This type of research is preexperimental using the static group comparison design. There are 2 treatment groups: PET bottled water that is exposed and not exposed to sunlight. The results showed that there were microplastics in PET bottled water exposed and not exposed to sunlight. Samples of bottled PET which exposed to sunlight have microplastic's number of 175 particles/liter. Whereas bottled water that was not exposed to sunlight has microplastic's number of 132,25 particles/liter. Independent t-test showed that the Sig (2-tailed) value was 0,023. This value less than $\alpha=0,05$. So, we can say that there were differences between both of them. The conclusion of the study was that there were differences in the number of microplastics between PET bottled water exposed and not exposed to sunlight. As a form of vigilance, the public is advised to deliver PET bottled water from direct sunlight both for distribution and other type utilization of PET bottles for other purposes such as disinfection of water using sunlight (SODIS).
\end{abstract}

Keywords: Microplastics, PET Bottled Water, Sun, Environmental Health

\section{Introduction}

Bottled Drinking Water (AMDK) is water that has been processed, without other foodstuffs and food additives, packaged, safely for drinking (Regulation of The Industrial Ministry Number. 96 at 2011). There are 2 types of packaging used in bottled water, namely: packaging made of glass and packaging made of plastic. The majority of the bottled drinking water industry in Indonesia uses PET bottles as their packaging.

Azapagic stated that Polyethylene Thephthalate (PET) is a polyester polymer formed from the reaction between ethylene glycol and terephthalic acid or Dimethyl Terephthalate with the help of catalysts in the form of: Manganese (Mn), Cobalt (Co), Cadmium (Cd), Calcium (Ca), Tin $(\mathrm{Pb})$, Zinc (Zn), Titanium (Ti) and Germanium
(Ge). Phthalate isomers consist of: Orthophthalate, Isoftalat, and Tereftalat (Widoastuti, 2018).

The use of packaging with the PET type is only single use. When exposed to sunlight, the polymer layer in this type of bottle melts and releases carcinogens material that can migrate in the water. PET is also not resistant to high temperatures and will melt at a temperature of $85^{\circ} \mathrm{C}$ (Karuniastuti, 2019). Shandytias (2018) also stated that there were 10 chemical compounds missing and 4 chemical compounds that were detected recently in sample water exposed to direct sunlight in a Polyethylene Thephthalate (PET) bottle.

The results of research on bottled drinking water at the State University of New York show that 242 of 259 bottled drinking water (AMDK)

\footnotetext{
*E-mail: atyafumifa@gmail.com
} 
contain microplastics. Bottled Drinking Water (AMDK) tested comes from brands that are sold freely in a number of countries such as: Indonesia, Thailand, India, the United States to San Pellegrino. The global average number of particles is 314.6 per liter (Sherri Mason, et al, 2018).

An international workshop about the existence of microplastics that was held on 9-11 September 2008 at the University of Tacoma USA has agreed that microplastics are plastic fragments with a size of $330 \mu \mathrm{m}<5 \mathrm{~mm}$. Apart from microplastics, there are also nano plastics which are plastic fragments with a size of $<330 \mu \mathrm{m}$.

Microplastics can accumulate in high amounts in seawater and sediments (Massura $\mathrm{J}$, 2015). Factors that can affect the degradation of plastics to microplastics include: fungi, bacteria, predators, higher organisms, hydrolysis, oxidation, washing, sunlight, climate, and mechanical stress (Widianarko and Hantoro, 2018).

According to Hollman, microplastics can be harmful to human health. Because if the microplastic is in the lumen, these particles can interact with the blood and carry out adsorption, then fill in proteins and glycoproteins. These events can affect the immune system and result in inflammation of the intestines. The very small size of the microplastics also allows transport to other organ tissues. Microplastics can also act as intermediaries that carry microbes into the waters. It is feared that microplastics that have contaminated the biota at various trophic levels can accumulate at lower trophic levels. (Neily Qurrota A'yun, 2019).

Apart from the opinions of experts regarding the effects of microplastics on human health, the World Health Organization (WHO) has a different opinion. The organization states that the level of microplastics in drinking water is not yet so harmful to human health at present. This is based on his research on the impact of exposure to microplastics in tap and bottled water. Microplastics larger than $150 \mu \mathrm{m}$ are unlikely to be absorbed by the human body. However, nano-sized particles are more likely to be absorbed by the body (VOA Indonesia, 2019).

A polymer that is exposed to sunlight can undergo photochemical aging, including in the case of the PET plastic type. This type of polymer can absorb sunlight which has a wavelength range $(\lambda)$ according to the UV light spectrum $(300 \mathrm{~nm} \leq \lambda \leq$ $330 \mathrm{~nm}$ ). Sun exposure of PET Bottles can also increase the temperature of the water. Based on these 2 things, there is a risk of changing the formation of chemicals from the bottles and their migration into water which, if consumed, can cause harm to consumers (Bach, et al., 2014).

PET bottles should not be exposed to direct sunlight. But many of us find that in sales activities, this bottled water can be deliberately or not exposed to direct sunlight. This has the risk of creating more microplastics than before.

The purpose of this study was to determine whether or not there is a difference in the number of microplastics in exposed and non-sun exposed bottled drinking water.

\section{Material and Method}

This type of this research is pre-experimental with the static group comparison design. The sample of this research is Bottled Drinking Water (AMDK) Brand $\mathrm{X}$ which is one of Indonesia's products. The packaging used as the sample was a $600 \mathrm{ml}$ volume PET bottle. Samples were purchased at Warung Sedulurku which is located \pm $1 \mathrm{~km}$ north of Campus 7, Poltekkes Kemenkes Semarang. The samples used were intact in the cardboard box and stored in a room that was not exposed to sunlight when they had not been purchased.

The identification of microplastics was carried out in 2 stages, namely: sample preparation and analysis. Sample preparation was carried out by sampling $500 \mathrm{ml}$ of bottled water and filtering water samples using Whattman GF / F filter paper (Ruzz, et al, 2014). The analysis stage was carried out by observing the filter paper using a $40 \mathrm{x}$ magnification binocular microscope. The analysis method in this way can provide information about the shape and color of microplastics (Agnes Veronica V., 2017).

\section{Result and Discussion}

\section{A. The Amount of Microplastic at The First Treatment}

Table 1. Result of Microplastic's Measurement

\begin{tabular}{ccc}
\hline Num. & Sample Code & $\begin{array}{c}\text { The Amount of } \\
\text { Microplastics } \\
\text { (particles/ liter) }\end{array}$ \\
\hline 1. & I1 & 70 \\
\hline 2. & I2 & 110 \\
\hline 3. & I3 & 110 \\
\hline 4. & I4 & 60 \\
\hline 5. & I5 & 90 \\
\hline 6. & I6 & 140 \\
\hline 7. & I7 & 180 \\
\hline 8. & I8 & 190 \\
\hline 9. & I & 140 \\
\hline 10. & I10 & 110 \\
\hline 11. & I11 & 150 \\
\hline 12. & I12 & 130 \\
\hline 13. & I13 & 170 \\
\hline 14. & I14 & 120 \\
\hline 15. & I15 & 170 \\
\hline 16. & I16 & 160 \\
\hline & Average & 131,25 \\
\hline
\end{tabular}

Source: Primary Data 
Based on the tests that have been carried out, microplastics were found in all samples of Brand X bottled drinking water. The average micro-plastic found in the samples was 131.25 particles / liter. The highest number of microplastic particles was found to be 190 particles / liter. Meanwhile, the number of microplastics was found to be at least 70 particles / liter. Through this analysis, it is also known that the classification of microplastics based on their shape is as shown in the following diagram.

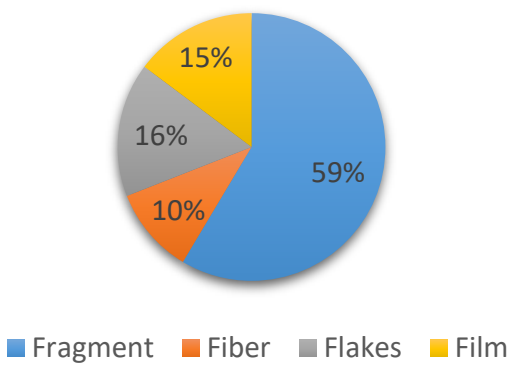

Picture 1. Microplastic's Classifications Doe to The Shape at The First Treatment

The number of microplastics contained in the AMDK treatment 1 sample was not different from the results of the analysis in the control sample. This is because the number of microplastics at least in treatment 1 is 70 particles / liter, meanwhile, the results of microplastic analysis on control bottled water are 80 particles / liter.

Treatment 1 whose sample conditions were not likely to differ from that of the control had results similar to that of the study conducted by Sherri A. Mason. This research at Fredonia State University of New York took samples of Brand X PET bottled water in 3 cities in Indonesia, namely: Jakarta, Bali, and Medan. The average microplastics found in the samples from the threecities were 37.1 particles / liter, 705 particles / liter, and 404 particles / liter. Samples taken in Jakarta have a newer production time than samples from Bali and Medan which have the same productiontime (Sherri A. Mason, et al, 2018).

Students from the University of North Dakota (UND) also examined the amount of microplastics in drinking water casks, bottled water and local soft drinks that were there. The results showed that the average number of microplastics in bottled drinking water samples was 101 particles / liter. This amount is less than the microplastics found in casks and soft drinks. The most common microplastics are fragments (Mansurat Golden A.A., 2019).

The bottled drinking water (AMDK) production process has been designed to minimize the possibility of microplastic contamination.
However, according to Mintenig (2019), some components of water treatment and distribution networks are made of plastic, then erosion or degradation of this material can contribute to the existence of microplastics in water. Oßmann (2018) argues that bottles and caps from some bottled drinking water bottles made of plastic can be a special source of the presence of microplastics in water (WHO, 2019).

Microplastics that enter the human body from bottled water will enter the digestive tract. This can lead to absorption of microplastics by body tissues. This opinion is evidenced by the results of research that particles smaller than 150 $\mu \mathrm{m}$ can enter through the gastrointestinal epithelium in mammals and cause systemic exposure. However, scientists speculate that the hope is that only $0.3 \%$ of these particles will be absorbed (Claudia Campanale, 2020).

Microplastics in bottled water can be reduced by processing water completely. One of the mineral water production processes is a filtration process using a micro filter, so that particles larger than the filter pores will not be able to escape. However, the Lancet Planetary Health (2017) states that data on microplastics in drinking water and how to eliminate them are still very limited (WHO, 2019).

\section{B. The Amount of Microplastic at The Second Treatment}

Table 1. Result of Microplastic's Measurement

\begin{tabular}{ccc}
\hline Num. & Sample Code & $\begin{array}{c}\text { The Amount of } \\
\text { Microplastics } \\
\text { (particles/ liter) }\end{array}$ \\
\hline 1. & O1 & 100 \\
\hline 2. & O 2 & 200 \\
\hline 3. & O3 & 240 \\
\hline 4. & O 4 & 100 \\
\hline 5. & O5 & 160 \\
\hline 6. & O6 & 140 \\
\hline 7. & O $~$ & 190 \\
\hline 8. & O $~$ & 130 \\
\hline 9. & O9 & 180 \\
\hline 10. & O10 & 230 \\
\hline 11. & O11 & 290 \\
\hline 12. & O12 & 140 \\
\hline 13. & O13 & 100 \\
\hline 14. & O14 & 180 \\
\hline 15. & O15 & 290 \\
\hline 16. & O16 & 130 \\
\hline & Average & 175 \\
\hline Sor
\end{tabular}

Source: Primary Data

The results of microplastic analysis in treatment 2 showed that the average microplastic found in the sample was 175 particles/ liter. The 
highest number of microplastic particles was found to be 290 particles/ liter. Meanwhile, the number of microplastics was found to be at least 100 particles/ liter. Through this analysis it is also known that the classification of microplastics is based on their shape as in the following diagram.

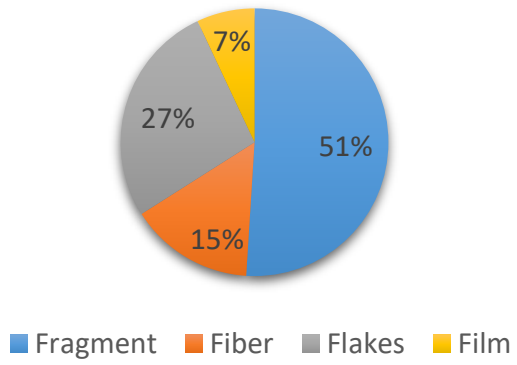

Picture 2. Microplastic's Classifications Doe to The Shape at The Second Treatment

The average number of microplastics found in treatment 2 was higher than the average number of microplastics in the thesis and dissertation research conducted by Abdulmalik Ali at the University of North Dakota (UND). The study states that the average number of microplastics found in local bottled water there is 101 particles / liter, while treatment 2 has an average number of microplastics 175 particles / liter. This is because the types of PET used in bottled water are not the same. In addition, Abdulmalik Ali's research did not expose bottled drinking water to sunlight, whereas treatment 2 was the opposite. Meanwhile, some of the samples examined by Sherri A. Mason had higher numbers of microplastics than this result. In fact, this study did not expose AMDK to sunlight.

The previous discussion stated that UV light can cause polymers to undergo photo-oxidation. This occurs with the mechanism of light absorption by the polymer which results in degradation in the form of chemical changes and the composition of the polymer macromolecules (Hamza Lamnii, et al., 2018). Photo-oxidation is a process that can give rise to microplastics. However, until now there has been no more in-depth and specific research on the effect of solar UV light on the existence of microplastics from exposed PET bottles.

There are different opinions regarding the health effects of microplastics. However, the majority of scientists state that particles with a size $<150 \mu \mathrm{m}$ can enter the human body tissue (Campanale, Massarelli, Savino, Locaputo, and Uricchio, 2020). According to Hollman, microplastics can be harmful to human health. Because if the microplastics are in the lumen, these particles can interact with the blood and carry out adsorption, then they will fill in proteins and glycoproteins (Neily Qurrota A'yun, 2019).

The number of microplastics in bottled water can be reduced by maintaining the performance of the bottled drinking water (AMDK) processing system. If possible, it is recommended that water treatment installations use materials that are not made of plastic. However, if there are no other materials, then the installation conditions must be checked periodically and when there are conditions that are less than perfect, they should be replaced immediately.

Microplastic in the treatment of 2 Brand X PET bottled water can be overcome by keeping the PET bottles from being exposed to direct sunlight. This has been stated on the cardboard packaging from AMDK PET Brand X. The use of PET bottles from AMDK as a tool for solar disinfection (SODIS) should also be avoided. Instead, SODIS can be done by using a glass bottle which is more resistant to sunlight. In addition, bottled drinking water sellers should also prevent bottles from being exposed to sunlight by not displaying them in the open or selling them using closed containers.

C. Statistic Analysis About The Differenceness at The First and Second Treatment

The T-Independent test results show that the $\mathrm{T}$ test value is 0.023 . This value is smaller than $\propto$, so it can be interpreted that $\mathrm{HO}$ is rejected and $\mathrm{Ha}$ is accepted. This means that there are differences in the number of microplastics in treatment 1 and treatment 2 or before and after exposure to sunlight.

The difference in the number of microplastics in the 2 treatments could be caused by the influence of sunlight containing ultraviolet rays. Hamza Lamnii et al (2018) stated that exposure to UV light for at least 5 hours can cause a mechanical effect on cracked polyethylene parts. This effect can increase with the length of exposure. Samples of Brand X bottled drinking water that were not exposed to sunlight already contained microplastics.

Sunlight can cause photo-oxidation of existing microplastics, so that the particles found in treatment 2 are more. Even so, the UV rays used in Hamza Lamnii's study came from lamps with a minimum dose of $32 \mathrm{Watt} / \mathrm{m} 2$, while the sun's UV exposure for 6 hours did not reach that dose. The previous discussion has also stated that the average microplastic in treatment 2 is less when compared to the research of Sherri A. Mason who took samples of Brand $\mathrm{X}$ bottled drinking water in Medan and Bali. Meanwhile, the samples were not exposed to sunlight. 
Based on this fact, it can be seen that statistical differences between samples of bottled bottled PET brand $\mathrm{X}$ exposed and not exposed to sunlight have the opportunity to be no different when compared to other studies. Therefore, there needs to be further research with the same treatment to achieve external validity. The previous discussion has also stated that the average microplastic in treatment 2 is less when compared to the research of Sherri A. Mason who took samples of Brand $\mathrm{X}$ bottled drinking water in Medan and Bali. Meanwhile, the samples were not exposed to sunlight.

So, we can say tatistical differences between samples of bottled bottled PET brand X exposed and not exposed to sunlight have the opportunity to be meaningless if it compared to other studies. Therefore, there needs to be further research with the same treatment to achieve external validity.

\section{Conclussion}

All samples of Brand X bottled drinking water that were not exposed to sunlight contained microplastics. The average number of microplastics in the bottled water which was not exposed was 131.25 particles / liter. Meanwhile, the average number of micro-plastic particles in bottled water exposed to sunlight is 175 particles / liter. The results of the Independent $\mathrm{T}$ test show that the Sig (2-tailed) value is 0.023 or $<0.05$. This means that there are differences in the number of microplastics in Brand $\mathrm{X}$ bottled PET that are not exposed to sunlight.

\section{Refferences}

A’yun, Neily Qurrata. (2019). “Analisis Mikroplastik Menggunakan FT-IR pada Air, Sedimen dan Ikan Belanak (Mugil cephalus) di Segmen Sungai Bengawan Solo yang Melintasi Kabupaten Gresik". Skripsi. Universitas Islam Negeri Sunan Ampel Surabaya.

Abdulmalik Ali, Mansurat Golden. (2019). "Presence And Characterization of Microplastics In Drinking (Tap/Bottled) Water and Soft Drink". Thesis dan Desertasi. UND Scholary Commons.

Bach, C., Dauchy, X., Severin, I., Munoz, J.-F., Etienne, S., \& Cagnon, M.-C. (2014). Effect of Sunlight Exposure on The Release of Intentionally and / or Non-intentionally Added Substance from Polyethylene Terephthalate (PET) Bottles into Water: Chemical Analysis and In Vitro Toxicity. Elsevier: Food Chemistry, 63-71.
Campanale, C., Massarelli, C., Savino, I., Locaputo, V., \& Uricchio, V. F. (2020). A Detailed Review Study on Potential Effects of Microplastics and Additives of Concern on Human Health. MDPI International Journal of Environmental Research and Public Health, 1-26.

Karuniastuti, N. (2019). Bahaya Plastik terhadap Kesehatan dan Lingkungan. Forum Teknologi, 6-14.

Lamnii, H., Moussa Nait-Abdelaziz, G. A., Gloaguen, J.-M., Maschke, U., \& Mansoor, B. (2018). Effect of UV Ageing on The Fatigue Life of Bulk Polyethylene. MATEC Web of Conferences 165, 08002 (2018) (hal. 1-6). Lille: EDP Sciences.

Mason, S. A., Welch, V., \& Neratko, J. (2018). Synthetic Polymer Contamination in Bottled Water. Fredonia: Fredonia State University of New York.

Massura J, e. a. (2015). Laboratory Methods for The Analysis of Microplastics in The Marine Environment. National Oceanic and Atmospheric Administration. NOAA Technical Memorandum, 47-48.

Menteri Perindustrian RI. (2011). Peraturan Menteri Perindustrian Republik Indonesia Nomor 96 Tahun 2011 tentang Persyaratan Teknis Industri Air Minum Dalam Kemasan. Jakarta: Kementerian Perindustrian Republik Indonesia.

Mintenig, S.M., et al. (2019). Low Numbers of Microplastics Detected in Drinking Water from Ground Water Sources. Science of The Global Environment, Vol. 5 halaman 648:631

OßMann BE, et al. (2018). Small-sized Microplastics and Pigmented Particels in Bottled Mineral. Water Research Vol. 16 halaman 141-307.

Pirzadeh, E., Zadhoush, A., \& Haghighat, M. (2007). Hydrolitic and Thermal Degradation of PET Fibers and PET Granule: The Effects of Crystallization, Temperature and Humidity. InterScience, 1544-1549.

Ruzz, H., et.al. (2012). Microplastics in the Marine Environment: A Review of the Methods. Environmental Science \& Technology, 60-75.

Samadi. (2007). Geografi 1 SMA Kelas X. Yudhistira: Jakarta.

Viktoria, A. V. (2017). Kontaminasi Mikroplastik di Perairan Tawar. Teknik Kimia, Institut Teknologi Bandung, 1-4.

VOA. (2019, Desember 2). Lingkungan Hidup. Diambil kembali dari Voaindonesia: https://www.voaindonesia.com/amp/who- 
mikroplastik-pada-air-minum-belum-

menjadi-masalah-kesehatan-/5052342.html

Widianarko, B., \& Hantoro, I. (2018). Mikroplastik dalam Seafood dari Pantai Utara Jawa. Semarang: Universitas Katholik

Soegijapranata.

Widoastuti, Shandytias. 2018. " Kontaminasi Di-(2Ethylexyl) Phthalate (DEHP) dari Botol Polietilena Tereftalat (PET) pada Air Minum SODIS di Yogyakarta Tahun 2018. Skripsi. Jurusan Kesehatan Lingkungan Politeknik Kesehatan Kementerian Kesehatan Semarang.

World Health Organization (WHO). (2019). Microplastics in Drinking Water. Switzerland. 